\title{
Effect of Structural Empowerment and Work Autonomy on Innovative Work Behavior in Plantation Companies
}

\author{
Gustiarti Leila' $^{1}$ Hamidah $^{2}$, Dede Rahmat Hidayat ${ }^{3}$ \\ ${ }^{1,2,3}$ Universitas Negeri Jakarta, Indonesia. \\ Corresponding Author: Gustiarti Leila
}

DOI: https://doi.org/10.52403/ijrr.20220142

\begin{abstract}
Innovative work behavior is a key factor for the effectiveness and survival of the organization in the face of competition in the free market. Therefore, it is important to conduct research on what factors can increase innovative work behavior. This study aims to examine the effect of structural empowerment and work autonomy on innovative work behavior in Plantation Companies. Respondents in this study were 173 supervisor level employees from state-owned plantation companies in Indonesia who were selected by simple random sampling technique. Structural equation modeling is used to test the hypothesis of this research. The findings show that work autonomy has a positive and significant effect on innovative work behavior, but structural empowerment has no effect on increasing innovative work behavior. Suggestions in this study are the need for a mediator variable so that structural empowerment can improve innovative work behavior.
\end{abstract}

Keywords: Structural Empowerment, Work Autonomy, Innovative Work Behavior

\section{INTRODUCTION}

Increased market competition supported by technological advances has a major impact on every company. Not only changing the pattern of interaction between sellers and buyers, technological advances have also changed the market environment to be more dynamic. This condition makes companies have to compete at the local, regional and global levels. One way companies face competition is to innovate.

Innovation is very important for the company's performance and the sustainability of its competitive advantage. Companies that have high competitiveness will become competitive companies. Scott and Bruce (1994) refer to the term innovation at the individual level as individual innovative behavior, which is further translated as innovative work behavior. One option for organizations to become more innovative is to encourage their employees to behave in an innovative manner (Agarwal, 2014). To encourage an increase in employee innovative behavior, the company should carry out several management interventions, among others, by building empowerment programs and facilitating employees to work independently.

Employee empowerment is an important organizational issue. Employees who are empowered with new ideas and an innovative work environment can improve their ability to respond more effectively in the face of changes in today's work environment (Chang and Liu, 2008). The results of Hebenstreit's research (2012) found a significant and positive correlation between structural empowerment and innovative behavior in employees. The research of Singh and Sarkar (2019) states that structural empowerment leads to innovative behavior of employees. The 
results of this study indicate that one method that can be used by companies to improve employee innovative behavior is through empowerment, by providing access to information, support, opportunities and resources needed. Kanter (1993) argues that the result of empowerment is the work system becomes decentralized, the hierarchical distance becomes smaller and there is an increase in employee participation.

Another factor that can affect the increase in innovative behavior is the provision of work autonomy to employees. Work autonomy refers to the degree of decision that employees have with regard to determining which tasks are to be performed and how to schedule, assign, and carry them out (Hackman and Oldham, 1975). Work autonomy shows a fairly strong relationship with innovative behavior, especially in the application of innovation which cannot be separated from the policies implemented by company leaders (Spielegaere, 2014).

Autonomy provides a sense of freedom to the extent that employees have responsibility for controllable outcomes, which gives them more enthusiasm and motivation to complete tasks (Amabile, 1996; Hackman and Oldham, 1975). Autonomy refers to an employee's level of control over how to carry out his job duties (Hackman and Oldham, 1975). Autonomy allows employees to experiment with different work approaches and methods. This allows them to come up with ideas and develop them further through small-scale implementation of these ideas.

\section{LITERATURE REVIEW Structural Empowerment}

The two main concepts of employee empowerment are psychological empowerment and structural empowerment (Conger and Kanungo, 1988). The concept of structural empowerment originates from Kanter's theory of structural power in organizations, which describes the conditions of the work environment. Kanter's theory (2008) states that in an empowering work environment, the work activities of empowered employees will increase. Empowered employees have less work pressure and job burnout, and therefore, are more likely to complete their jobs successfully and be satisfied with their jobs.

Empowerment allows for personal growth of employees, which in turn will affect job achievement. Employees who feel empowered generally feel more satisfied with their jobs (Pandiangan, 2015).

Zimmerman (2000) states that the empowerment process is a process in which employees have control over work, obtain needed resources, and critically understand the social environment. The empowerment process is achieved if management can help individuals develop skills so that they can become problem solvers and independent decision makers (Pandiangan, 2018). Empowerment is contextual and specific to a population, meaning that empowerment is different for different people in different contexts. Employee empowerment is considered as a motivational practice that aims to improve performance by increasing employee opportunities to participate and be involved in decision making (Meyerson and Dewettinck, 2012). Empowerment is a mechanism for giving authority to employees to make decisions and is often associated with the division of responsibilities from managers to employees (Saif and Saleh, 2013). Empowerment results from decentralization carried out by management, the structural level is relatively flat, so that it can increase employee participation (Kanter, 2008).

The factors needed for empowerment are access to information, access to support, access to opportunities for growth and learning, and control over resources. Strength in the organization stems from the ability of employees to gain access to these four components of structural empowerment (Kanter, 2008):

1. Opportunities are opportunities to learn and develop, and grow in skills and knowledge. 
2. Resources are the ability to obtain the supplies, personnel, equipment, materials, time, and money needed to do one's job.

3. Information refers to the data, technical knowledge, and expertise required to function effectively in one's position.

4. Support which is the motivation, guidance, direction, assistance and feedback of those who work with you for a successful work outcome.

\section{Work Autonomy}

Work autonomy is defined as the extent to which work provides individuals with substantial freedom, independence, and discretion in scheduling work and in determining the procedures to be used in carrying it out (Pandiangan et al., 2018). Job autonomy is one of several core job design characteristics (skill variety, task identity, task significance, and job feedback) developed by Hackman and Oldham (1975). According to Hackman and Oldham (1975), work autonomy is the responsibility of a job that leads to high work effectiveness and high internal work motivation. Work autonomy describes the extent to which a job allows freedom, independence, and discretion to schedule work, make decisions, and choose the methods used to perform tasks (Morgeson and Humphrey, 2006). Autonomy plays an important role in the process of employee motivation. Autonomy refers to self-regulation because people have a basic psychological need for autonomy, which they want to fulfill (Ryan and Deci, 2006). The psychological experience of autonomy allows people to freely choose their activities.

Work autonomy, according to the classical definition, refers to the degree of control or discretion that a worker can exercise with respect to work methods, work schedules, and work criteria (Breaugh, 1985). Breaugh (1985) proposes to distinguish between three dimensions of job autonomy:

1. Autonomy of work methods refers to the degree of freedom of individual decisions regarding procedures, methods, and how the work is carried out.

2. Autonomy of work scheduling refers to the control that employees have over work schedules, work times, and sequences.

3. Autonomy of work criteria refers to the degree to which employees can choose or change work objectives and evaluation criteria.

\section{Innovative Work Behavior}

Innovative work behavior is defined as individual behavior that aims to introduce and implement new ideas, processes, products or procedures in a person's work, work group or organization Jong and Hartog (2010) that are beneficial to the organization and deserve to be displayed in their work (Mura et al., 2012). The importance of innovative behavior has become the concern of several companies in order to survive and have future prospects (Spiegelaere, 2014). Companies that have succeeded in creating competitive advantage are companies that are able to create innovation and creativity. Jong and Hartog (2010) distinguish four dimensions of innovative work behavior, and name them as idea exploration, idea generation, fighting for ideas, and implementing ideas. Exploration of ideas includes finding ways to improve a current product, service, or process or trying to think of an alternative. Idea generation relates to new products, services or processes, entry into new markets, improvements in current work processes, or in general finding solutions to identified problems. Struggling for ideas includes seeking support and building coalitions by expressing enthusiasm and belief about the success of the innovation, being persistent, and involving the right people (Howell et al., 2005). Implementing an idea is a sizable effort and a results-oriented attitude is required to make the idea a reality. Implementing ideas also includes making innovations part of Kleysen and Street's (2001) regular work processes and 
behaviors such as developing new products or work processes, and testing and modifying them (Kanter, 1988).

Janssen (2000) describes innovative behavior at work as a complex behavior consisting of a series of three different behaviors, namely: idea generation, idea promotion, and idea realization. Individual innovation begins with idea generation, i.e. producing new and useful ideas in the work environment.

The next behavior of the innovation process is the promotion of ideas to potential co-workers, meaning that after an employee generates an idea, he or she must engage in social activities to build a coalition of supporters that provides the necessary strength for the development of the idea. The last behavior of the innovation process concerns the realization of ideas that are applied in individual, group or organizational work roles as a whole (Janssen, 2010). Employee innovative behavior is the process of developing, adopting, and implementing new ideas for products, technologies and work methods carried out by employees, and is a determinant of organizational success (Bosnehles et al., 2016).

\section{Effect of Structural Empowerment on Innovative Work Behavior}

Structural empowerment, sometimes referred to as managerial empowerment, focuses on how individuals with power and authority in an organization (managers) share with those who lack it (employees) (Conger and Kanungo 1988; Fernandez and Moldogaziev, 2013). It derives from organizational theory with a major emphasis on the delegation of power and authority (Knol and Linge 2009). Structural empowerment implies that lower-level employees in an organization are enabled to take appropriate action through a set of structures, practices, and policies within the organization that result from smoothing the hierarchy (Seibert et al., 2011). Previous studies have found that structural empowerment has a significant effect on innovative behavior, which means that when employees are given the power to carry out their duties, employees will carry out their work with full responsibility and innovation (Singh and Sarkar, 2019; Echebiri, 2020; Knol and Linge, 2009; Mercy et al., 2020; Rhee, 2017).

Based on Kanter's theory of structural empowerment, Kanter identified four structures of work empowerment: information, resources, support and opportunity (Kanter, 1977, 1979). Research shows that having access to information, receiving support, having access to the necessary resources to do one's job and having the opportunity to learn and grow are perceived as empowering structures. When employees are structurally empowered, manifestation within the organization is reflected by access to this structure which is facilitated by formal job characteristics (Laschinger et al., 2001). Echebiri et al. (2020) found that structural empowerment and psychological empowerment had a direct positive relationship with employee innovative behavior. This finding is theoretically meaningful, because structural empowerment in an organization provides employees with significant opportunities, information, support and effort to generate, develop, and implement innovative ideas. These findings suggest that empowerment is a useful and promising concept for enabling employees to engage in innovation activities.

H1: Structural empowerment has a positive and significant effect on innovative work behavior.

\section{Effect of Work Autonomy on Innovative Work Behavior}

Autonomy has taken a central place in various job design theories (Hackman and Oldham, 1975; Bakker and Dameruti, 2007). Work autonomy refers to the level of decision that employees have with regard to determining which tasks are to be performed and how to schedule, assign, and carry them out, thus allowing employees to experiment with different approaches and methods 
(Hackman and Oldham, 1975). Work autonomy allows employees to discover ideas and develop them further through small-scale implementation of these ideas.

The meta-analysis of Hammond et al. (2011) stated that work autonomy has a strong relationship with innovative behavior. A number of studies have argued that autonomy directly impacts innovative behavior (Takaishi et al., 2019). The results of previous studies stated that work autonomy had a significant effect on innovative work behavior (Spiegelaere et al., 2014; Orth and Volmer, 2017; Sonmez and Yildirim, 2019; Takaishi et al., 2019).

$\mathbf{H}_{2}$ : Work autonomy has a positive and significant effect on innovative work behavior

\section{RESEARCH METHODS}

\section{Research Design and Respondent}

This study examines the theoretical model using a single data source obtained from supervisor-level employees of a stateowned plantation company. The study used a quantitative approach and survey method with a questionnaire designed using a rating scale for positive items, scores ranging from 1 (strongly disagree) to 5 (strongly agree), while for negative items, a score of 1 (strongly agree to) to 5 (strongly disagree). Quantitative methods emphasize objective measurements and the statistical, mathematical, or numerical analysis of data collected through polls, questionnaires, and surveys, or by manipulating pre-existing statistical data using computational techniques (Pandiangan et al., 2021).

The data collection technique was simple random sampling which was collected from a sample population of supervisor level employees, using a questionnaire that was distributed directly through the google form application. Simple random sampling is a subset of the statistical population in which each member of the subset has the same probability of being selected (Octiva et al., 2018). The number of data collected was 173 responses, consisting of $91 \%$ men and $9 \%$ women, with tenure ranging from 1 year to more than 30 years.

\section{Measures}

The innovative work behavior instrument is an adaptation of the innovative work behavior scale developed by Janssen (2000) which measures the indicators of idea generation, idea promotion, and idea realization. The number of items before and after the trial was 9 items. Cronbach's alpha 0.918. The structural empowerment instrument is an adaptation of the structural empowerment scale developed by Echebiri (2020) which is based on Kanter's (1977) theory, measuring indicators of information power, resource power, support power, and opportunity power. The number of items before the trial is 17 items and after the trial is 16 items, Cronbach's alpha is 0.899 . While the work autonomy instrument used is an adaptation of the work autonomy scale developed by Breaugh (1985) which measures the indicators of work method autonomy, work scheduling autonomy, and work autonomy criteria. The number of items before the trial was 12 items and after the trial was 8 items. Cronbach's alpha 0.759

\section{Hypothesis Test}

Hypothesis testing using the SmartPLS software. SmartPLS is a software with a graphical user interface for variancebased structural equation modeling using the partial least squares path modeling method (Tobing et al., 2018).

\section{RESULT AND DISCUSSION Sample Descriptive Statistics}

Table 1 is a descriptive statistic of the sample of the variables used in this study, with a sample of 173 respondents. The table describes the average value, standard deviation, variance of the variables structural empowerment (EMP), work autonomy (WA), innovative work behavior (IWB).

Table 1 presents the mean, standard deviation, and variance of the study 
variables. The mean value for structural empowerment ranges from 3.8509 to 4.0116 and the standard deviation is between 0.55435 to 0.63700 . Meanwhile, the mean value of work autonomy ranged from
3.5913 to 3.9393 and the standard deviation was between 0.70586 to 0.82373 . The mean value of innovative work behavior ranged from 3.6081 to 3.8092 and the standard deviation was between 0.62248 to 0.68338 .

Table 1: Sample Descriptive Statistics

\begin{tabular}{|l|c|c|c|c|c|}
\hline & $\mathbf{N}$ & Range & Mean & Std. Dev. & Variance \\
\hline EMP1 $\left(\mathrm{X}_{1} .1\right)$ & 173 & 2.20 & 3.8509 & .60517 & .366 \\
\hline EMP2 $\left(\mathrm{X}_{1} .2\right)$ & 173 & 2.00 & 3.9543 & .61987 & .384 \\
\hline EMP3 $\left(\mathrm{X}_{1} .3\right)$ & 173 & 2.00 & 4.0116 & .55435 & .307 \\
\hline EMP4 $\left(\mathrm{X}_{1} .4\right)$ & 173 & 2.00 & 3.9653 & .63700 & .406 \\
\hline WA1 $\left(\mathrm{X}_{2} .1\right)$ & 173 & 3.00 & 3.9393 & .78545 & .617 \\
\hline WA2 $\left(\mathrm{X}_{2} .2\right)$ & 173 & 3.00 & 3.5913 & .70586 & .498 \\
\hline WA3 $\left(\mathrm{X}_{2 .} .3\right)$ & 173 & 3.30 & 3.6746 & .82373 & .679 \\
\hline IWB1 (Y.1) & 173 & 3.00 & 3.8092 & .68338 & .467 \\
\hline IWB2 (Y.2) & 173 & 3.00 & 3.7624 & .62248 & .387 \\
\hline IWB3 (Y.3) & 173 & 3.30 & 3.6081 & .66046 & .436 \\
\hline Valid N (listwise) & 173 & & & & \\
\hline
\end{tabular}

\section{Convergent Validity}

Table 2: Cronbach's Alpha, Composite Reliability, AVE, Indicator's Outer Loading

\begin{tabular}{|c|c|c|c|c|c|}
\hline Variable & $\begin{array}{c}\text { Cronbach's } \\
\text { Alpha }\end{array}$ & $\begin{array}{l}\text { Composite } \\
\text { Reliability }\end{array}$ & $\begin{array}{l}\text { Average Variance } \\
\text { Extracted (AVE) }\end{array}$ & $\begin{array}{c}\text { Indicator's } \\
\text { Outer Loading }\end{array}$ & Description \\
\hline $\begin{array}{l}\text { Innovative Work Behavior Indicator: } \\
\text { IWB1 } \\
\text { IWB2 } \\
\text { IWB3 }\end{array}$ & 0.859 & 0.914 & 0.779 & $\begin{array}{c}- \\
0.887 \\
0.880 \\
0.882\end{array}$ & $\begin{array}{c}\text { Reliable and } \\
\text { Valid }\end{array}$ \\
\hline $\begin{array}{l}\text { Structural Empowerment Indicator: } \\
\text { EMP1 } \\
\text { EMP2 } \\
\text { EMP3 } \\
\text { EMP4 }\end{array}$ & 0.857 & 0.897 & 0.686 & $\begin{array}{c}- \\
0.787 \\
0.786 \\
0.861 \\
0.873\end{array}$ & $\begin{array}{c}\text { Reliable and } \\
\text { Valid }\end{array}$ \\
\hline $\begin{array}{l}\text { Work Autonomy Indicator: } \\
\text { WA1 } \\
\text { WA2 } \\
\text { WA3 }\end{array}$ & 0.651 & 0.807 & 0.584 & $\begin{array}{l}- \\
0.815 \\
0.661 \\
0.807\end{array}$ & $\begin{array}{c}\text { Reliable and } \\
\text { Valid }\end{array}$ \\
\hline
\end{tabular}

Table 2 shows Cronbach's alpha, composite reliability, average variance extracted, indicator's outer loading.

All values are above 0.7 for Cronbach's alpha and composite reliability and 0.5 for average variance extracted Hair (2014), meaning that all indicators on the variables meet the convergent validity criteria.

\section{Discriminant Validity}

All quadratic correlations of the first-order latent variables were found to be less than the mean of the extracted variances as desired (Fornell and Larcker, 1981). This indicates that the items share a more general variance with their respective constructs. In addition, the weighted factor scores were high for constructs within the construct itself and low for other constructs, clearly establishing discriminant validity.

\section{Analysis}

In this study, innovative work behavior is the dependent variable, while the variables of structural empowerment and work autonomy are independent variables. Hypothesis testing using Smart PLS software, because the number of samples is less than 200

The results of the $\mathrm{H}_{1}$ test show that there is no effect of structural empowerment on innovative work behavior $(\beta=0.174$, $\mathrm{p}=0.085>0.05)$. While the results of the $\mathrm{H}_{2}$ test showed that there was a positive and significant effect of work autonomy on innovative work behavior $\quad(\beta=0.323$, $\mathrm{p}=0.001<0.05)$.

\section{DISCUSSION}

Many previous studies have stated that structural empowerment has a direct and significant relationship with innovative 
work behavior. However, in this study, no direct relationship was found between empowerment and innovative work behavior. This can be explained based on the characteristics of the sample, in which the sample in this study are employees of state companies who have fairly structured work characteristics and have routine and standard achievement targets. Meanwhile, in terms of organization, state companies have many rules and signs that must be obeyed. Therefore, although the government urges these state-owned companies to be more innovative, there is a possibility that the implementation has not been fully implemented, the company has not intervened by empowering all employees to be more innovative so that it has not become a work culture in this company.

The results of this study can also be explained based on Hofstede's cultural dimension theory (2011) which states that the culture of people in the eastern world, including Indonesian society, has a relatively high cultural value in terms of power distance. In this type of culture, employees tend to prefer top managers to take greater control of work processes and lead by example. Thus, employees with high power distance cultures are likely to feel confused when left alone to figure out what they need to do and how to achieve their goals. To take an innovative approach to work usually requires risky decision making, while empowerment itself if not accompanied by guidance and some structured measures can lead to negative consequences in a high power distance culture. High power distance shows a culture that is very dependent on hierarchy, inequality of rights between power holders and ordinary people, the leader is directive, has full power and controls everything. This condition is in line with the cultural picture in plantation companies, so that there is no significant relationship between empowerment and innovation behavior because employees are most likely to rely heavily on hierarchies and power holders, which causes empowerment not to be directly related to employee innovative behavior.

The results of the statistical test of the direct effect of work autonomy on innovative work behavior give the results of the path coefficient values showing significant results. This means that work autonomy has a positive and significant effect on the innovative behavior of employees in that population. The results of this study are in line with the results of previous studies which say that there is a direct and significant influence between work autonomy and employee innovative behavior. Spiegelaere's (2014) research on the effect of job insecurity on innovative behavior through the mediator variables of work autonomy and engagement shows the results that work autonomy has a very strong influence on innovative behavior compared to other variables. Consistent results were also found in the study of Spiegelaere et al. (2015) which examines the relationship between job design and employee engagement and innovative behavior. The results show that work autonomy has a direct and significant effect on innovative behavior. Research by Orth and Volmer (2017) shows that work autonomy has a direct and positive effect on employees' innovative behavior.

The existence of work autonomy allows employees to experiment with different work approaches and methods. This allows them to come up with ideas and develop them further through application in their work. When jobs are designed in such a way that employees have autonomy, employees are free to carry out their duties based on their own judgment and preferences. By granting work autonomy, employees will be more flexible to regulate their work, work schedules, and work criteria for themselves so as to allow them more flexibility to develop their ideas in carrying out their duties. That is why the higher the employee perceives the company to provide autonomy, the higher the innovative ideas that can be carried out by employees. 


\section{CONCLUSION}

This study analyzes the effect of structural empowerment on innovative work behavior to understand the structural empowerment mechanism that drives innovative work behavior. In addition, it also analyzes the effect of work autonomy on innovative work behavior, in order to understand that giving work autonomy to employees can encourage an increase in innovative work behavior. In this study, increasing innovative work behavior can only be done by facilitating employees to work independently so that it is expected to be able to generate small ideas to improve employee performance for the better. Structural empowerment is not able to directly influence innovative work behavior, it may require the role of an appropriate mediator variable so that it can play a role in increasing innovative work behavior.

Suggestions in this study are the need for a mediator variable so that structural empowerment can improve innovative work behavior.

\section{Acknowledgement: None}

\section{Conflict of Interest: None}

\section{Source of Funding: None}

\section{REFERENCES}

1. Amabile, T. M. (1996). Creativity in Context: Update to the Social Psychology of Creativity. Boulder CO: Westview Press.

2. Azwar, S. (2019). Reliabilitas dan Validitas. Yogyakarta: Pustaka Pelajar.

3. Bos-nehles, A., Bondarouk, T., \& Nijenhuis, K. (2016). Innovative Work Behaviour in Knowledge-Intensive Public Sector Organizations: the Case of Supervisors in the Netherlands Fire Services. The International Journal of Human Resource Management, 5192(10). https://doi.org/10.1080/09585192.2016.124 4894.

4. Breaugh, J. A. (1985). The Measurement of Work Autonomy. Human Relations, 38(551).https://doi.org/10.1177/0018726785 03800604.

5. Chang, L. C., \& Liu, C. H. (2008). Employee Empowerment, Innovative
Behavior and Job Productivity of Public Health Nurses: a Cross-Sectional Questionnaire Survey. International Journal of Nursing Studies, 45(10), 1442-1448. https://doi.org/10.1016/j.ijnurstu.2007.12.00 6.

6. Echebiri, C., Amundsen, S., \& Engen, M. (2020). Linking Structural Empowerment to Employee-Driven Innovation: the Mediating Role of Psychological Empowerment. MDPI, 10(42).

7. Fernandez, S., \& Moldogaziev, T. (2013). Using Employee Empowerment to Encourage Innovative Behavior in the Public Sector. Journal of Public Administration Research and Theory, 23(1), 155-187. https://doi.org/10.1093/jopart/ mus008.

8. Hebenstreit, J. J. (2012). Nurse Educator Perceptions of Structural Empowerment and Innovative Behavior. Nursing Education Perspectives, 33(5), 297-301.

9. Janssen, O. (2000). Job demands, Perceptions of Effort-Reward Fairness and Innovative Work Behavior. Journal of Occupational and Organizational Psychology, 287-302. https://doi.org/ 10.1016/j.aquaculture.2010.01.018.

10. Jong, De, J., \& Den Hartog, D. (2010). Measuring Innovative Work Behaviour. Creativity and Innovation Management, 19(1), 23-36.https://doi.org/10.1111/j.14678691.2010.00547.x.

11. Kanter, R. M. (1993). Men and Women of the Corporation. New York: Basic Books.

12. Meyerson, G., \& Dewettinck, B. (2012). Effect of Empowerment on Employees Performance. Abstract, 2(7), 40-46.

13. Morgeson, F. P., \& Humphrey, S. E. (2006). The Work Design Questionnaire (WDQ): Developing and Validating a Comprehensive Measure for Assessing Job Design and the Nature of Work. 91(6), 1321-1339. https://doi.org/10.1037/00219010.91.6.1321.

14. Mura, M., Lettieri, E., Spiller, N., \& Radaelli, G. (2012). Intellectual Capital and Innovative Work Behaviour: Opening the Black Box Regular Paper. International Journal of Engineering Business Management, 4, 1-10.

15. Octiva, C. S., Irvan, Sarah, M., Trisakti, B., \& Daimon, H. (2018). Production of Biogas from Co-digestion of Empty Fruit Bunches (EFB) with Palm Oil Mill Effluent (POME): 
Effect of Mixing Ratio. Rasayan J. Chem., 11(2), 791-797.

16. Orth, M., \& Volmer, J. (2017). Daily Within-Person Effects of Job Autonomy and Work Engagement on Innovative Behaviour: the Cross-Level Moderating Role of Creative Self-Efficacy. European Journal of Work and Organizational Psychology, 26(4), 601-612. https://doi.org/10.1080/1359432X.2017.133 2042.

17. Pandiangan, Saut Maruli Tua. (2015). Analisis Lama Mencari Kerja Bagi Tenaga Kerja Terdidik di Kota Medan. Skripsi. Medan: Fakultas Ekonomi dan Bisnis, Program Studi Ekonomi Pembangunan, Universitas Sumatera Utara. https://www.academia.edu/52494724/Analis is_Lama_Mencari_Kerja_Bagi_Tenaga_Ker ja_Terdidik_di_Kota_Medan.

18. Pandiangan, Saut Maruli Tua. (2018). Analisis Faktor-faktor yang Mempengaruhi Penawaran Tenaga Kerja Lanjut Usia di Kota Medan. Tesis. Medan: Fakultas Ekonomi dan Bisnis, Program Studi Ilmu Ekonomi, Universitas Sumatera Utara. http://repositori.usu.ac.id/bitstream/handle/1 23456789/10033/167018013.pdf?sequence $=$ $1 \&$ isAllowed=y.

19. Pandiangan, Saut Maruli Tua, Rujiman, Rahmanta, Tanjung, Indra I., Darus, Muhammad Dhio, \& Ismawan, Agus. (2018). An Analysis on the Factors which Influence Offering the Elderly as Workers in Medan. IOSR Journal of Humanities and Social Science (IOSR-JHSS), 23(10), 76-79. DOI:10.9790/0837-2310087679.

http://www.iosrjournals.org/iosr-jhss/ papers/Vol.\%2023\%20Issue10/Version8/K2310087679.pdf.

20. Pandiangan, Saut Maruli Tua, Resmawa, Ira Ningrum, Simanjuntak, Owen De Pinto, Sitompul, Pretty Naomi, \& Jefri, Riny. (2021). Effect of E-Satisfaction on Repurchase Intention in Shopee User Students. Budapest International Research and Critics Institute-Journal, 4(4), 77857791. DOI: https://doi.org/10.33258/birci. v4i4.2697.

21. Saif, N. I., \& Saleh, A. S. (2013). Psychological Empowerment and Job
Satisfaction in Jordanian Hospitals Philadelphia University Philadelphia University. International Journal of Humanities and Social Science, 3(16), 250257.

22. Singh, M., \& Sarkar, A. (2019). Role of Psychological Empowerment in the Relationship Between Structural Empowerment and Innovative Behavior. Management Research Review, 42(4), 521538. https://doi.org/10.1108/MRR-04-20180158.

23. Spiegelaere, De, S., Van Gyes, G., De Witte, H., Niesen, W. (1861). Job Design, Work Engagement and Innovative Work Behavior: a Multi-Level Study on Karasek's Learning Hypothesis. 26(2), 123-137. https://doi.org/10.1688/mrev-2015-02DeSpiegelaere.

24. Spiegelaere, De, S., Van Gyes, G., De Witte, H., Niesen, W., \& Van Hootegem, G. (2014). On the Relation of Job Insecurity, Job Autonomy, Innovative Work Behaviour and the Mediating Effect of Work Engagement. Creativity and Innovation Management, 23(3), 318-330. https://doi.org/10.1111/caim.12079.

25. Takaishi, K., Sekiguchi, K., Kono, H., \& Suzuki, S. (2019). Interactive Effects of Work Autonomy and Proactive Personality on Innovative Behavior. 4(1), 6-16. https://doi.org/10.20849/abr.v4i1.548.

26. Tobing, Murniati, Afifuddin, Sya'ad, Rahmanta, Huber, Sandra Rouli, Pandiangan, Saut Maruli Tua, \& Muda, Iskandar. (2018). An Analysis on the Factors Which Influence the Earnings of Micro and Small Business: Case at Blacksmith Metal Industry. Academic Journal of Economic Studies, 5(1), 17-23. https://www.ceeol.com/search/articledetail?id=754945.

How to cite this article: Gustiarti Leila, Hamidah, Dede Rahmat Hidayat. Effect of structural empowerment and work autonomy on innovative work behavior in plantation companies. International Journal of Research and Review. 2022; 9(1): 351-359. DOI: https:// doi.org/10.52403/ijrr.20220142 